\author{
POLITYKA ENERGETYCZNA - ENERGY POLICY JOURNAL \\ $2020 \uparrow$ Volume $23 \uparrow$ Issue $4 \uparrow 91-104$ \\ DOI: $10.33223 / \mathrm{epj} / 127300$
}

Tetiana ZHYBER $^{1}$, Tetiana SolopenKo ${ }^{2}$

\title{
The implementation of Ukraine's energy policy using budget programs
}

ABSTRACT: The research is devoted to the organization of the energy policy objectives implementation through programs. A country's energy policy can be monitored in many ways. The article proposes to consider the implementation of energy policy objectives with the budget programs maintenance on the example of Ukraine. Budget programs make it possible to trace the dynamics of changes in the aim and directions of the authorities' energy policy, implemented for budgetary funds. With the budget programs since 2002 in Ukraine, it was possible to trace the increase in spending on the coal industry, highlight the funding forced of negative consequences in the energy sector and separate the steps to develop an energy strategy. Changes in the totality of energy policy budget programs are shown, their contents are considered. The decrease in the budget programs number associated both with the enlargement of their aim and with the withdrawal expenses for reconstruction and social protection of those affected by the previous energy activities from the budget funding. To assess budget programs planning and implementation uniformity the author's integrated indicator is proposed. It takes the funding level and the quality indicator implementation on assignment directions into account. The calculation of the indicator showed that the expenditures for the general

$\triangle$ Corresponding Author: Tetiana Zhyber; e-mail: tzhiber@gmail.com

${ }^{1}$ Department of Finance, Kyiv National Economic University named after Vadym Hetman, Ukraine; ORCID iD: 0000-0002-4557-023X; e-mail: tzhiber@gmail.com

2 Department of Finance, Kyiv National Economic University named after Vadym Hetman, Ukraine; ORCID iD: 0000-0002-4662-6936; e-mail: tanya060194@ukr.net

2020. The Author(s). This is an open-access article distributed under the terms of the Creative Commons Attribution-ShareAlike International License (CC BY-SA 4.0, http://creativecommons.org/licenses/by-sa/4.0/), which permits use, distribution, and reproduction in any medium, provided that the Article is properly cited. 
management of the energy policy and for scientific development are planned in the programs more evenly than the expenses for the energy strategy implementation.

KEYWORDS: energy policy, program management, program budgeting, controlling in energy policy implementation

\section{Introduction}

The energy policy implementation by the Government of Ukraine requires expenditures of taxpayers' money. The authorities' implementation of Ukraine's energy policy components depends on central budget financing. Central budget funding tied to the policy objectives with the budget programs help Ukraine use the option of tracking a particular direction of expenditures by the budget programs and its executors (MFP 2019; STSU 2019). The budget program is a specifically structured part of the budget plan and reporting, linking the amount of the funds with the results of their use. The calculation of changes in the real priorities of energy policy by the budget programs with the possibility of distributing, for example, management, investment or liquidation costs, has been possible since 2002 in Ukraine (Zhyber 2018).

Since the budget programs' content in Ukraine started published relatively recently, existing studies about the linkage between programs indicators, goals and funding had not related directly to the energy policy. The publication (Erastov and Novikova 2015) is devoted to the integral indicator development in estimating the effectiveness of energy conservation programs in the aggregate; indicator interpretation sapid for this study.

The budget program combines estimates in finance with the programs tasks and performance indicators which detail the implementation of the program during the budget period (which has been lasting for a year now). Performance indicators are an integral part of the budget program. They are called "result indicators of the budget program" and describe the desired program directions execution along the logical chain "costs - product - unit cost of the product (which is interpreted as efficiency) - quality of the performance (percentage expression of the level of the achieved result)". The number of the budget programs result in indicators varied from 2-3 to a dozen per group. Every responsible executor completes some budget programs during the budget year. The names and the number of budget programs showed changes in the financing of the energy policy from the budget from the construction for public funds towards the development of a strategy and provision of forced costs for residual phenomena.

The Ministry of Energy or its counterparts were mainly responsible for the energy policy implementation. However with the budget programs, it could possible to reveal that part of the costs due to the related decisions in the energy sector were subordinated to the Ministry of Finance (mainly based on the results of financial obligations servicing) or the Ministry of Social Policy (expenses on transfers due to price regulation as a part of energy policy) time to time 
(STSU 2019). Budget programs by responsible authorities as a tool in the public budget reports allowed observers to identify the expenditures on energy policy directions.

The energy policy implementation in the line performers' context examined; expenses on the energy policy of Ukraine clarified with the help of expenditures for the aims of budget programs and their executors. Discrepancies between actual and planned budget expenditures interrelated with a performance indicator of the budget program titled "quality" taken as a primary measure of the energy policy implementation quality was deliberated. The consideration of an additional calculation for the current assessment of the energy policy implementation - an integrated indicator of the actual budget programs finance and performance indicator's deviations from their planned objectives in the state budget expenses on energy policy was proposed. The integral current assessment could measure the smoothness of the energy policy tasks financing planning in the transfer period from yearly to mid-term budgeting.

\section{The context of energy policy implementation in Ukraine}

After gaining independence, electricity production in Ukraine decreased by $40 \%$. Back in 1990, Ukraine supplied $40 \%$ of the USSR's nuclear power industry, but within the country $66.7 \%$ of the electricity was produced by thermal power plants, and only $24.8 \%$ by nuclear energy (Landau and Sigal ed. 2011). This led to continuous spending from the budget for partially private coal energy and unprofitable state nuclear power. The coal industry, unlike other sources of electricity production, has been financed by the state budget as a separate line since Ukraine gained independence. Salary arrears and unprofitable mines were covered by public funds. Alternative "green" electric power began to occupy more than $1 \%$ of the electricity generated in Ukraine's total volume only in the middle of the last decade; its part amounted to $1.5 \%$ of total electricity production at the beginning of 2020. The development of green energy was not directly financed from the budget, unlike coal and nuclear enterprises, other financial instruments like high prices to stimulate investment are used (Metelytsya et al. 2020).

The largest percentage in the production of electricity in Ukraine is formally occupied by nuclear power nowadays: $48.6 \%$ in 2014 and $54.9 \%$ at the beginning of 2020 . However, in the structure of electricity production, coal-gas-fuel sourced electricity accounted for $45.5 \%$ in 2014 and $35.4 \%$ at the beginning of 2020 ; the coal-dependent structure of electricity production is supported by a number of economic and social ultimatums (Petlovanyi et al. 2018), which causes the current aggravation of the political requirement for quotas for the use of Ukrainian coal in the production of electricity (UEA 2020). Oksana Voytyuk demonstrates the special role of DTEK in organizing coal supplies for the electricity generating industry in Ukraine in a particular case of the import blockade in his article "Energy blockade of Donbass and its consequences for Ukraine" (Voytyuk 2019). Brown coal extracting costs has partly been compensated from the state budget to domestic mines during for 20 years in Ukraine. The dependence of the electric 
power industry on coal supports continued government funding of replacing imported coal with domestic coal, including through the refurbishment of the Thermal Power Stations and funding for the research and development of new coal production technologies (Petlovanyi et al. 2018).

Costs for the prevention of landslides and flooding of waste excavations had also become constant for the central budget. The existence of such budgetary programs of the coal industry has remained unchanged since 2002: the restructuring (liquidation) of mines, rescue operations, construction of the Novovolynskaya mine. The requirement of domestic coal supplies also claim for the budget programs to inject budget funding to the coal industry: a program for the reconstruction of mines, programs for the closure of used parts of coal mining enterprises and for lifelong support in a safe condition of all the worked out mines, a program for coal industry efficiency improving through the modernization of facilities, covering salary arrears from the budget and compensation of the cost of a ton of coal to the special estimated selling price. The forced state budget expense due to the energy policy consequences of the activities of both state and private mines are shown in Figure 1.

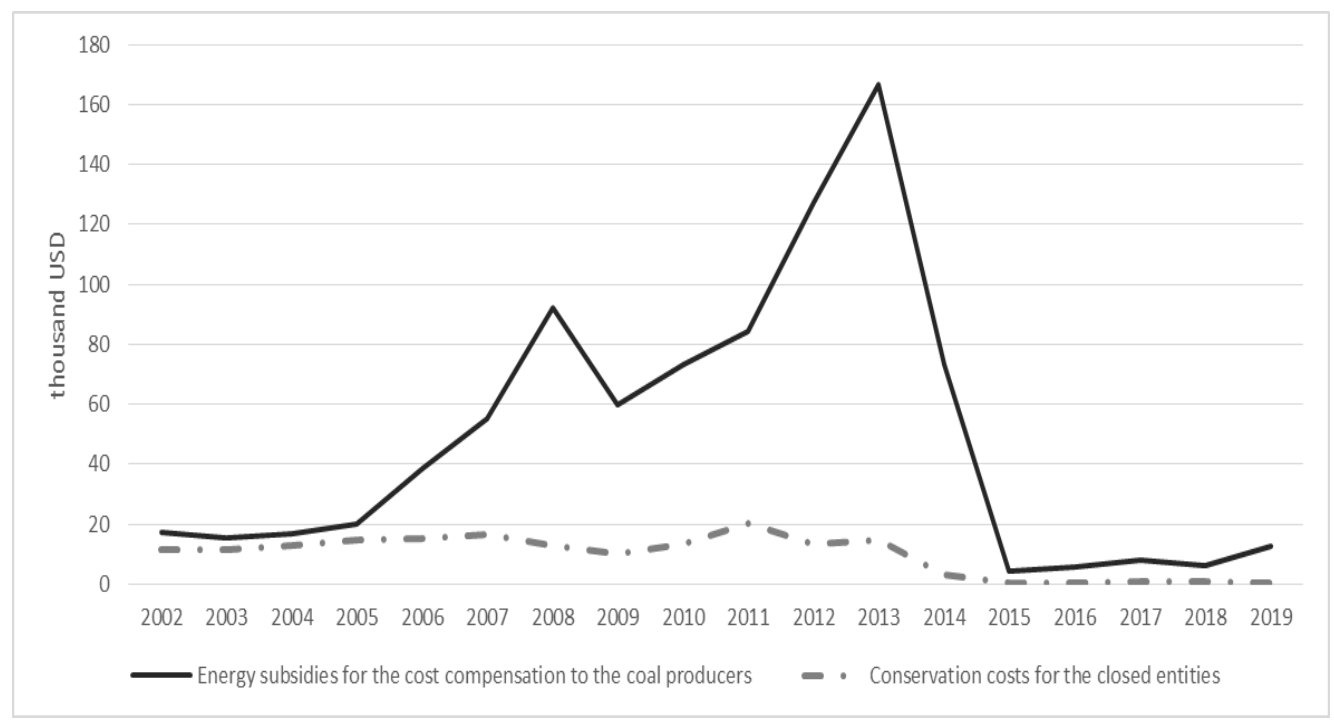

Fig. 1. Forced long lasting central budget expenses on the coal industry in Ukraine Source: own study based on (STSU 2019)

Rys. 1. Wymuszone długotrwałe wydatki budżetu państwa na przemysł węglowy na Ukrainie

According to the reporting data, in 2013 (before the crisis and the occupation of eastern Ukraine), compensation of the coal production cost 125 state mines about from the state budget reached $0.94 \%$ of the country's GDP. Accordingly, the cost of materials (coal), which by 2014 amounted to $83.5 \%$ of TPP fuel has been growing constantly (Chernousenko 2014). The graph in Figure 2 also reflects the occupation of Donbass in 2014 and an attempt to switch to the price regulation of unprofitable operations of coal mining enterprises. 
The special role of the coal industry for electricity production influences the institutional environment of the energy policy and the line of the Ministry of Energy. The Ministry of Fuel and Energy was responsible for budget programs within the energy policy in 2002, in 2006 the Ministry of Coal was additionally allocated, and in 2011 a unified Ministry of Energy and Coal Industry began to construct budget programs for the energy policy. In 2019, the Ministries of Energy and Environmental Protection of Ukraine was merged, but after 5 months of 2020, these Ministries were again divided due to conflicting tasks in the joint budget programs, and the current energy policy was assigned to the Ministry of Energy of Ukraine. The remainder of the previous Ministry of Coal Industry was not eliminated at the beginning of 2020, but it is not allowed to manage the budget programs this year. Simultaneously, for some time there has been no entity responsible for publishing the reports of the former joint Ministry for 2019 on the implementation of budget programs in the electric power industry. Dynamic changes in the institutional responsibility for the energy policy resulted in the fact that the budget program's objectives were referred from smaller and more specific to an enlarged structure of the budget programs. The Ministry of Energy grouping of the energy policy goals mainly related to the energy production issues, which is currently implemented.

The administrative reform of 2004 curtailed the powers of the President of Ukraine in favor of the Parliament, and Governments in Ukraine sometimes changed more often than once a year. Policy makers did not have time to monitor the implementation of the budgets they initiated. In part, such an institutional policy caused the allocation in this publication precisely the planned budget expenditures indicators without assessing the institutional impact on them and without assessing the quality of the midterm goals formulation by the main governors in the energy sector. The full implementation the present linkage of indicators to the level of the energy policy strategic goals fulfillment in Ukraine was limited by the unpredictable current activity (Berezhny and Shatylo 2013), which is expressed in the immeasurability of the strategic goals set, examples of which are indicated below.

The Ministry responsible for energy policy began publishing the full content of budget programs (budget programs passports, for example (MEU 2020)) for the expenditures, related to the energy sector policy, and reports on their execution in 2014, made it possible to compare planned and actual performance indicators of energy policy tasks implementation in the current budget periods. Prior to this, the costs of energy policy in the context of the budget programs purpose were available only as the expenditure data in the state budget annual report on the execution of the general and special funds, where the special fund provided for paid services and other special incomes. 


\section{Budget programs design in the energy sector}

The number of budget programs devoted to the implementation of energy policy objectives decreased from 57 in 2002 to 19 items in 2014, which was caused by the consolidation of tasks to be solved with their help. The actual number of budget programs regarding energy policy totals around 20 .

The design of the titles (identical to the purpose) of the specialized budget programs in their changes dynamics since 2002 shown in Figure 2. Energy-related aims of responsible institutions for purpose budget funding had been linked with the activities of the budget executors.

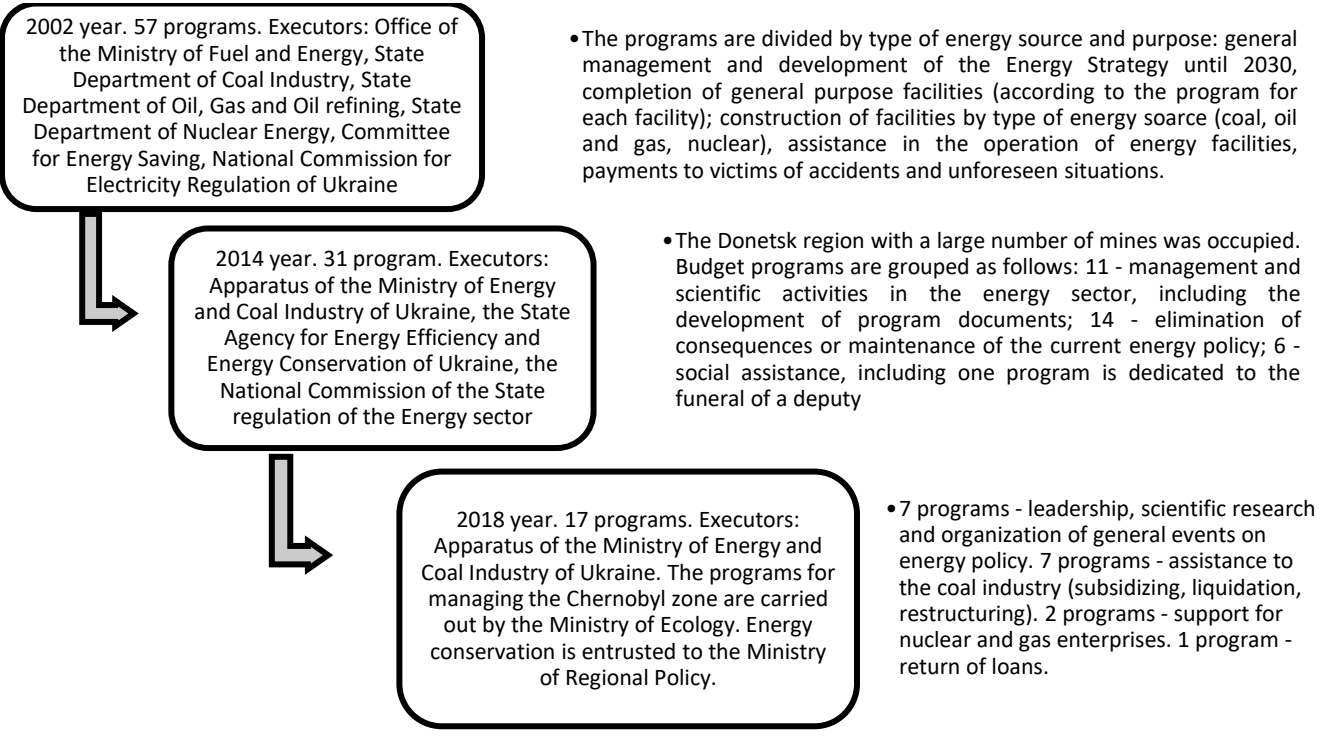

Fig. 2. Combination of the budget programs, related for energy policy in Ukraine Source: own study based on (STSU 2019)

Rys. 2. Połączenie programów budżetowych związanych z polityką energetyczną Ukrainy

Figure 2 shows the decreased diversification of the energy policy objectives with the state budget funding since 2002. Initiatives have been partly moved to the credit budgeting (such as transmission lines updating or hydropower modernizing with the help of international assistance (Zhyber 2018). Also, financial regulation schemes for the activities of energy entities were used (for example, the formula for linking the price of coal to the international Rotterdam + , special duty on imported fuel, etc.). These changes show preparation for the diversification of the electricity market in Ukraine, necessary to avoid a cross-subsidization of the electricity producers (Dergachova and Pysar 2018). The global goal is set in order to achieve and provide Ukraine's energy independence (Yemelyanov et al. 2018). 
Taking the coal industry as example, it can be argued that financing from Ukraine's budget should be divided into forced support for the consequences of the energy policy and the development of a promising energy strategy.

In Table 1 budget programs have been grouped in actual spending after the Donbass occupation and current spending. The following objectives were highlighted: ensuring the development and implementation of the Energy Strategy of Ukraine, management and scientific developments in the energy sector, budget programs for the reconstruction, maintenance and restructuring of capacities (direct maintenance of used coal and peat mining sites, regardless of the form of ownership), budget expenditure programs to improve the efficiency of the energy sector, budget programs to streamline the consequences of the Chernobyl disaster.

TABLE 1. Budget programs expenditures by objectives in budget spending on the energy sector policy [\%]

TABELA 1. Wydatki programów budżetowych według celów polityki energetycznej [\%]

\begin{tabular}{|l|c|c|c|c|}
\hline \multicolumn{1}{|c|}{ Objective group } & 2014 year & 2019 year & $\begin{array}{c}\text { Difference } \\
2019-2014\end{array}$ & $\begin{array}{c}1 \text { quart. of 2020 } \\
\text { (actual) }\end{array}$ \\
\hline $\begin{array}{l}\text { General governance of the energy } \\
\text { sector }\end{array}$ & 0.65 & 5.71 & +5.06 & 5.22 \\
\hline Scientific Developments & 0.19 & 1.11 & +0.92 & 1.08 \\
\hline Subsidies and compensatory steps & 86.42 & 18.24 & -68.18 & 6.55 \\
\hline Restructuring & 11.75 & 69.75 & +58.00 & 87.06 \\
\hline $\begin{array}{l}\text { Energy Strategy and Program of } \\
\text { Development }\end{array}$ & 0.97 & 0.31 & -0.66 & 0.9 \\
\hline
\end{tabular}

Source: own study based on (STSU 2019).

The energy policy budget programs spending structure has changed significantly. The percentage of strategic management and scientific development policies in total energy policy spending has increased, while subsidies for direct electricity generation have lost the share of costs.

To divide the budget expenditures for the implementation of the state energy policy in two main directions proposed. The first purpose of expenditures is the forced unavoidable costs of eliminating or maintaining the consequences of the previous state energy policy. In Ukraine, the main three reasons for such costs are: a) the Chernobyl disaster; 2) maintaining the ecological balance in the place of old coal and peat workings and places of extraction of nuclear raw materials; 3) the dependence of the balance of the energy system on coal and gas raw materials. The second group of expenditures includes expenditures for the implementation of the state policy in the energy sector, which concludes the energy policy for the future. Based on the existing list, it refers to permanent budget programs of the strategic direction: a) strategic support for energy management through the development and implementation of program documents and b) the costs of the state administration, which organizes the implementation of energy policy, including the implementation of scientific developments. In the publication, such expenses counted only 
within the central budget of Ukraine, since the financial support of national aims of the energy sector concerns national functions and law delegated to local authorities.

\section{Assessment of the planned energy policy accomplishment within budget programs}

Based on the Budget Code of Ukraine, the budget expenditure construction can assess the formulated directions of expenditures by the implemented tasks of the budget programs within the framework of energy policy. Table 1 shows the increasing importance of development expenditures in the energy policy. The calculation of an integral indicator based on the allocation for development purposes for the current assessment of the implementation of the declared goals based on the results of budget periods and the scope of expenditure is proposed. A specified formula proposed for the quality indicator of the budgetary program on the development of the energy policy, which also includes the part of the program direction's actual financing during implementation, as suggested (Erastov and Novikova 2015). The assessment indicator is based on the quality indicators of budget programs and actual financing of the program's directions. This mean the product of the level (percentage) of actual expenditures in the budget programs direction to the plan of expenditures on the energy policy of the current budget period and the percentage of deviation of the budget program's implementation actual quality indicators in this direction from the previously planned ones. This indicator is proposed for measuring the level of under-fulfillment of the planned results of the integration of the program directions for the funding and completing of their tasks without reference to their quantitative measurement in money, which in dynamics can show the plan imbalance of the state energy policy strategic goal achievement.

Since the indicators are based on the developed indicators of the budget program its best value will be 1 , or $100 \%$ fulfillment of the budget program in terms of financing and quality to the initially planned level.

The sequence for calculating the indicator is as follows. The first factor - the quality of funds allocation in the budget program directions - should be considered as the level of the actual indicator in the planned expenditures in the event of the deviation of actual expenditures from the planned ones at the end of the period (budget program executed). The formula for the performance of program expenditures in percentage terms will be as follows:

$$
s_{i}=s_{a} / s_{p} \cdot 100
$$

where:

$s_{a}-$ the amount of planned expenses in direction of the budget program,

$s_{p}-$ the amount of funds actually allocated in direction at the end of the budget period and drawn up on the budget program report. 
Deviations of the actual performance indicators of the program (program direction) quality from the planned ones for a specific direction of the budget program $q_{i}$ are indicated in the report on the budget program execution as a percentage of underperformance of the quality indicator in the direction.

If there are several quality indicators in the direction of the budget program, the formula for determining the total deviation of quality in the $q_{i}$ direction will be constructed as follows:

$$
q_{i}=\sum_{j=1}^{m} p_{j}
$$

where:

$p_{j}-$ the percentage deviation of the actual performance indicator of the program quality from its planned value in their totality by the number $j$ in the direction $i$.

The formula for the integral assessment of the quality of achieving the planned goal in the direction of the energy policy budget program (IE) will be as follows:

$$
I E=\sum_{i=1}^{n}\left(s_{i} \cdot q_{i}\right) / 100
$$

where:

$s_{i}-$ the level of fulfillment of the actual expenditures allocated in the directions in the budget program structure for the energy policy from the state budget by the total number $n$,

$q_{i}$ - the deviation of the quality indicators of the achievement of the "program's objective" in these spheres for a certain budget period. Budget programs are formulated with unpredictable non-standardized expenditure directions, but not less than one.

An integral assessment formula proposed for the every year repeating energy policy budget program's tasks. Applying it to investment and restructuring programs may make it difficult fully appreciate the final objective. For example, the budget program executed in 2018, which has been in existence since 2002, has the final objective "State construction of the Novovolynskaya mine". Within the strategic aim "Satisfying the economy's need for the necessary coal reserves" two quality indicators were envisaged and fulfilled: 1) construction costs for the budget period consists of $34.9 \%$ from the project amount (deviation from the plan was 0 ); 2 ) the degree of construction readiness of the facility at the end of the budget period $-87.6 \%$ (deviation from the plan was 0 ). At the same time, the actual expenditure of budgetary funds in the direction of the program also fully coincided with the planned one. Thus, the integral indicator of actual deviations in the quality of this program from the planned energy policy was 100 , or $100 \%$ achievement of the set goal in the current budget period. However, the construction of this facility has lasted for over 18 years. 


\section{Results of the energy policy budget programs directions execution}

Table 2 shows the sequence of indicators of the current budget programs in strategic energy policy. The essence of the budget program is the grouping of the budget funds spending results into four groups the performance indicators with a group of quality indicators of the budget program execution, but they concern only the current budget period. The "efficiency indicator" is described, which is mainly the cost per unit of the budget programs product, and is not included in Table 2 to facilitate its structure.

TABLE 2. Budget programs expenditures example detailing by the purposes

TABela 2. Przykładowe wydatki programów budżetowych z wyszczególnieniem ich przeznaczenia

\begin{tabular}{|c|c|c|c|}
\hline $\begin{array}{l}\text { Purpose of the } \\
\text { budget program as part } \\
\text { of the strategic goal of } \\
\text { the energy policy }\end{array}$ & Cost indicators group & Product indicators group & $\begin{array}{l}\text { Indicators of the program } \\
\text { directions execution quality } \\
\text { (achievement of the goal in the } \\
\text { budget period) }\end{array}$ \\
\hline $\begin{array}{l}\text { Implementation of state } \\
\text { policy in the energy } \\
\text { sector }\end{array}$ & $\begin{array}{l}\text { Number of employees; area of } \\
\text { premises; number of budget } \\
\text { institution's cars; number of } \\
\text { official journeys; number of } \\
\text { memberships in international } \\
\text { energy organizations }\end{array}$ & $\begin{array}{l}\text { The number of processed papers, } \\
\text { applications, claims; the number } \\
\text { of scheduled inspections of ener- } \\
\text { gy enterprises; number of finan- } \\
\text { cial plans drawn up }\end{array}$ & $\begin{array}{l}\text { Percentage of orders completed } \\
\text { on time, processed requests; } \\
\text { percentage of claims won; the } \\
\text { percentage of inspection cove- } \\
\text { rage of energy sector enterpri- } \\
\text { ses; level of the membership } \\
\text { financial obligations fulfillment }\end{array}$ \\
\hline $\begin{array}{l}\text { Applied scientific and } \\
\text { educational } \\
\text { activities in the energy } \\
\text { sector }\end{array}$ & $\begin{array}{l}\text { Number of organizations, } \\
\text { number of developments, } \\
\text { number of high-priority deve- } \\
\text { lopments }\end{array}$ & $\begin{array}{l}\text { The number of developments } \\
\text { completed in the budget period, } \\
\text { the number of developments in- } \\
\text { troduced in the budget period }\end{array}$ & $\begin{array}{l}\text { The percentage of priority de- } \\
\text { velopments in the total number } \\
\text { of developments, the percentage } \\
\text { of completed developments, the } \\
\text { percentage of implemented de- } \\
\text { velopments }\end{array}$ \\
\hline $\begin{array}{l}\text { Supporting } \\
\text { implementation of the } \\
\text { Energy Strategy } 2030 \\
\text { and the } \\
\text { Program of the } \\
\text { Energy Sector } \\
\text { development } \\
\text { (infrastructure } \\
\text { modernization) }\end{array}$ & $\begin{array}{l}\text { Cost of project implementa- } \\
\text { tion in the current budget pe- } \\
\text { riod, number of projects with } \\
\text { foreign support, number of } \\
\text { consultants involved, cost of } \\
\text { training programs }\end{array}$ & $\begin{array}{l}\text { The number of training programs, } \\
\text { the number of prepared program } \\
\text { documents, the number of trained } \\
\text { employees of the Ministry, the } \\
\text { number of reports on the imple- } \\
\text { mentation of initiatives, the amo- } \\
\text { unt of construction work carried } \\
\text { out }\end{array}$ & $\begin{array}{l}\text { Part of the budget funds used, } \\
\text { the level of readiness of pro- } \\
\text { gram documents, the level of } \\
\text { readiness of implementation } \\
\text { reports, the level of implemen- } \\
\text { tation of planned projects }\end{array}$ \\
\hline
\end{tabular}

Source: own study based on (MEU 2020).

Examples of current budget programs from Table 2 show the sequence of constructing indicators for the implementation of energy policy objectives in certain fields. The indicator of the 
quality of program execution participates in the integral indicator of the current assessment of the budget expenditures on energy policy capacity.

The results of calculating this qualitative indicator for budget programs directly reflect the strategic direction of the energy policy, namely the quality of general management in the field of energy policy implementation, scientific and educational activities, the development and implementation of the Energy Strategy and the National long-term Program for the Development of the Energy Sector. Dynamics of the calculated integrated indicator for the proposed assessment for 2014-2018 are shown in Table 3 for the recurring budget programs with the same purpose. The period after 2014 was taken not only because of the radical changes in the conditions of energy policy implementation due to the occupation of part of Ukrainain territories, but also because the Ministry of Energy start publishing the reports on the execution of budget programs in the public domain (MEU 2020).

TABLE 3. Integrated indicator of the current assessment of deviation from the implementation of the planned goal

TABELA 3. Zintegrowany wskaźnik bieżącej oceny odchyleń od realizacji planowanego celu

\begin{tabular}{|c|c|c|c|c|c|}
\hline Program directions & 2014 & 2015 & 2016 & 2017 & 2018 \\
\hline $\begin{array}{l}\text { Program for the General management } \\
\text { Direction 1. Ensuring the performance of functions } \\
\text { and tasks. } \\
\text { Direction 2. Repayment of accounts payable. } \\
\text { Direction 3. Payment of ship dues. } \\
\text { Direction 4. Purchases for electronic document } \\
\text { management. } \\
\text { Direction 5. Reform of public administration } \\
\text { (including computerization) } \\
\text { Track 6. Financial Commitments to NATO } \\
\text { on Energy Security } \\
\text { Track 7. Expenditure on NATO Energy } \\
\text { Security Center of Excellence } \\
\text { Overall Program Average Indicator for Budget Year }\end{array}$ & $\begin{array}{l}\text { D1. } 63.97 \\
\text { D2. } 90.98\end{array}$ & $\begin{array}{l}\text { D1. } 52.15 \\
\text { D2. } 100\end{array}$ & $\begin{array}{l}\text { D1. } 49.9 \\
\text { D2. } 100 \\
\text { D3. } 3416\end{array}$ & $\begin{array}{l}\text { D1. } 54,60 \\
\text { D3. } 14,64 \\
\text { D4. } 0 \\
\text { D5. } 36,1\end{array}$ & $\begin{array}{l}\text { D1. } 74 \\
\text { D3. } 18,01 \\
\\
\text { D5. } 48,63 \\
\text { D6. } 0 \text { (funding } \\
\text { not provided) } \\
\text { D7. } 0 \text { (funding } \\
\text { not provided) } \\
28,128\end{array}$ \\
\hline Scientific developments Program & 61,67 & 100 & 83,84 & 71,37 & 115,87 \\
\hline $\begin{array}{l}\text { Implementation of the Energy sector reform and } \\
\text { development Program } \\
\text { Direction 1. Payment for the services of consultants } \\
\text { Direction 2. Payment of VAT under international } \\
\text { consulting contracts }\end{array}$ & $\begin{array}{l}\text { D1. } 0 \\
\text { (quality } \\
\text { score not } \\
\text { met) } \\
\text { D2. } 0 \\
\text { (quality } \\
\text { score not } \\
\text { met) }\end{array}$ & $\begin{array}{l}\text { D1. } 138,64 \\
\text { D2. } 45,78\end{array}$ & $\begin{array}{l}\text { D1. } 78,47 \\
\text { D2. } 118,43\end{array}$ & D1. 8,26 & D1. 30,06 \\
\hline
\end{tabular}

Source: own study based on (MEU 2020). 
When the indicator exceeds 100 , this means the actual funding exceeded the originally planned budget in the budget program in the current budget period. The dynamics of the assessment shows the discrepancy between the launch of individual directions and the planned dates, the current priorities over changes. The indicator could purposefully be used in the system of current controlling of the implementation of the energy policy by the authorities. Calculated for the budget program as a whole (or the totality of the directions of spending within the program), this indicator, in addition to its negative or positive generalized deviations, can signal the homogeneity of the energy policy directions implementation within the framework of the single program's aim.

Therefore, according to the level of the budget funding execution and allocation for some directions of the program, it can be concluded that they were planned unexpectedly and did not ultimately become part of the budget process. The indicators of the budget programs tasks still more likely inform about the circumstances of the energy policy management in past periods than provide a basis for building a system of tasks in the energy sector.

\section{Conclusions}

Budget programs provide information on the use of budget funds for the energy policy by containing the main aims and objectives formulation. The task of the budget program could be carried out outside the specific executor in general by a changeover. With the help of such reporting, it is possible to track changes in energy policy objectives that were financed from the budget. On the one hand, such an instrument as the budget program increases the transparency of the energy policy detailing; on the other hand, its implementation during the budget period, sometimes with different tasks for one aim, portrayed the operational unpredictability of the annual budget planning of expenditures for the energy strategy in Ukraine. The operation deviations in the plan and actual results could be more hidden in the case of middle term budget programs.

When the reporting of budgetary funds executor is insufficient for the general energy policy dynamics, the focus of public funds reports shifted to detailing the budget classification. The operation assessment of the budget program's on energy policy directions implementation with the help of an integrated indicator based on yearly performance could be completed by the results of any reporting period, which allows for fixing the level of funding and performance of the expected program quality indicator.

Budget programs are formulated from an unpredictable non-standardized number of expenditure directions, but not less than one, the overall assessment of the program execution quality in the future can be calculated either by averaging the integrated indicator for the program, or averaging with additional weigh on the priority of the budget program direction. But the priority of directions for budget programs in their assessment in the budgetary practice of Ukraine has not yet been provided. 
The proposed integrated indicator within the current assessment of the program budgeting reporting framework of the central budget will make it possible to track systematic cumulative signs of budget programs qualitative underperformance in order to correct their content in the medium-term budget mode, which is planned to be introduced in Ukraine after 2021.

\section{References}

BEREZHNY, Y. and ShatYLO, O. 2013. Establishment of strategic planning and management in the energy sector of Ukraine (Запровадження стратегічного планування та управління в енергетиці України). Economy and State 11, pp. 94-99 (in Ukrainian).

Chernousenko, O. 2014. The state of Ukraine's energy sector and the results of modernization of TPP power units (Стан енергетики України та результати модернізації енергоблоків TEC). The National Academy of Sciences of Ukraine, Institute Of General Energy. The problems of general energy No 4, pp. 20-28 (in Ukrainian).

DERGACHOVA, V. and PySAR, N. 2018. Implementation of the market approach to the processes of management of the energy sector of ukrainian economy under conditions of European integration. Eastern-European Journal of Enterprise Technologies 3, pp. 40-49, DOI: 10.15587/1729-4061.2018.133437.

Erastov, A and Novikova, O. 2015. Method for calculating the integral indicator of the effectiveness of the implementation of regional energy saving programs (Методика расчета интегрального показателя эффективности реализачии региональных программ энергосбережения). Bulletin of the Ivanovo State Power Engineering University 3, pp. 73-80, DOI: 10.17588/2072-2672.2015.3.073-080 (in Russian).

LANDAU, J and Sigal, I. ed. 2011. Energy: history, present and future: Progress of nuclear energy and interconnected energy systems (Энергетика: история, настоящее и будущее: Развитие атомной энергетики и объединенных энергосистем). Kyiv, 304 pp. (in Russian).

Metelytsya, V. et al. 2020. The importance of financial lever in the management of alternative energy development. Financial and credit activity: problems of theory and practice 2(33), pp. 223-231; DOI: https://doi.org/10.18371/fcaptp.v2i33.206687.

MEU 2020. Budget programs executions Reports. Ministry of Energy of Ukraine (MEU). [Online] http:// mpe.kmu.gov.ua/minugol/control/uk/publish/officialcategory?cat_id=245001835 [Accessed: 2020-08-01] (in Ukrainian).

MFP 2019. State budget expenditure Report 2019. Ministry of Finance of Poland (MFP), State Budget Department. [Online] https://www.gov.pl/web/finance/state-budget [Accessed: 2020-07-10].

Petlovanyi, M.V. et al. 2018. Modern experience of low-coal seams underground mining in Ukraine. International Journal of Mining Science and Technology 28(6), pp. 917-923, DOI: 10.1016/j. ijmst.2018.05.014.

STSU 2019. State budget expenditure Report 2019 Subsection II.1. Expenditures according to the program classification of expenditures and crediting of the state budget Section II "Expenditures" of the Report on Execution of the State Budget of Ukraine (Підрозділ II.1 "Видатки за програмною класифікацією видатків та кредитування державного бюджету” розділу II “Видатки” Звіту про виконання Держсавного бюджету Украйни). State Treasury Service of Ukraine (STSU). [Online] https://www.treasury.gov.ua/ua/file-storage/vikonannya-derzhavnogo-byudzhetu [Accessed: 2020-07-10] (in Ukrainian).

UEA 2020. Regarding overcoming the crisis situation in the fuel and energy complex of Ukraine (Щодо подолання кризової ситуації в паливно-енергетичному комплексі України). Public Union “The 
Ukrainian energy Assembly" (UEA) Proposal for the President of Ukraine. [Online] https://vse.energy/ news/hotnews/1115-overcoming-the-crisis [Accessed: 2020-07-02] (in Ukrainian).

VoyTYuK, O. 2019. Energy blockade of Donbass and its consequences for Ukraine. Polityka Energetyczna - Energy Policy Journal 22(4), pp. 97-114, DOI: 10.33223/epj/111962.

Yemelyanov, O. et al. 2018. Evaluation of the Adaptability of the Ukrainian Economy to Changes in Prices for Energy Carriers and to Energy Market Risks. Energies 11(12), p. 3529, DOI: 10.3390/en11123529.

ZhyBer, T. 2018. Trends and Prospects of State Budget Expenditures on the Energy Sector of Ukraine (Тендениии и перспективы расходов из государственного бюджета на энергетический сектор Украины). Economy of Ukraine No 11-12, pp. 60-70 (in Russian).

\title{
Realizacja polityki energetycznej Ukrainy z wykorzystaniem programów budżetowych
}

\author{
Streszczenie
}

Przedstawione badania dotyczą sposobu realizacji celów polityki energetycznej poprzez programy budżetowe. Politykę energetyczną kraju można monitorować na wiele sposobów. W artykule zaproponowano rozważenie realizacji celów polityki energetycznej przy zachowaniu programów budżetowych na przykładzie Ukrainy. Takie programy pozwalają na śledzenie dynamiki zmian celu i kierunków polityki energetycznej, które władze realizują poprzez zastosowanie środków budżetowych. Analiza programów budżetowych od 2002 r. na Ukrainie pozwala zauważyć wzrost wydatków na przemysł węglowy; wskazuje, że to finansowanie wymuszone było negatywnymi zjawiskami występującymi w energetyce, oraz daje możliwość wyodrębnienia kolejnych etapów opracowywania strategii energetycznej. Przedstawiono zmiany w programach budżetowych dotyczących polityki energetycznej i omówiono ich treść. Spadek liczby programów budżetowych związany jest zarówno z poszerzeniem ich celu, jak i z wycofaniem ze środków budżetowych wydatków na modernizację oraz ochronę socjalną osób dotkniętych dotychczasową działalnością energetyczną.

Do oceny planów i dla zapewnienia jednolitości oceny realizacji programów budżetowych autorki zaproponowały zintegrowany wskaźnik. Uwzględnia on poziom finansowania oraz wskaźnik jakości poszczególnych kierunków działań. Wskaźnik ten udowodnił, że wydatki planowane na ogólne zarządzanie polityką energetyczną oraz na rozwój naukowy są bardziej równomierne niż wydatki na realizację strategii energetycznej.

SŁOWA KLUCZOWE: polityka energetyczna, zarządzanie programami, budżetowanie programów, kontroling w realizacji polityki energetycznej 